\title{
Very high radiation levels found in Swedish houses
}

FOLLOWING the discovery of extremely high concentrations of radioactive radon daughter elements in Swedish houses, a government committee has proposed measures to allow maximum concentrations far higher than would be internationally acceptable. The radon producing the daughters derives not only from radium in the soil and rock on which the houses are built, but also from radium in building materials.

The immediate cause of the high levels recently recorded, however, is energysaving. Enthusiasm for energy conservation has led many people to tape over their windows to keep the warmth inside; consequently ventilation rates have dived. With a ventilation rate of one air exchange every two hours, even the worst radon daughter levels are greatly reduced; but some of the houses measured have had only 0.2 air exchanges every two hours.

To overcome the conflict between energy saving and health, the committee suggests the installation of air exchangers in which the outgoing air would warm up the incoming air. Discussions are currently being held to decide how much financial assistance could be paid to house-holders for the necessary alterations, but at the moment it looks as though the amount will be small.

From the radon point of view, the worst building material used in Sweden is aerated concrete made from alum shale. Its manufacture was banned in 1974 for this reason, but it had been a popular building material for 45 years. At the other extreme is wood which contains practically no radium. Ironically enough, the houses whose high radioactivity led to the committee of enquiry were built of wood - but constructed on slag heaps left after the mining of alum shale. Only a small proportion of risk houses have so far been identified, and campaigns are being organised to find others. Current estimates of the numbers of houses that will have to be altered run as high as 15,000 .

The International Committee on Radiation Protection recommends that no member of the general public should be exposed for many years to an annual dose equivalent of more than 1 millisievert (mSv) of radiation, excluding natural background and medical sources. This level is estimated to give a lung cancer rate of one person in every thousand exposed for 60 years. There is as yet no internationally-agreed level for exposure to radon in houses. In the average Swedish house, the concentration of radon daughters gives a dose equivalent of 3 $\mathrm{mSv} / \mathrm{yr}$, assuming a person spends $80 \%$ of time indoors - and the worst cases found in the present investigation are as high as $100 \mathrm{mSv} / \mathrm{yr}$. "If nothing is done, our present building situation may cause up to 1100 cases of cancer in about 30 years", says the Director of the Radiation Protection Institute, Professor Bo Lindell.

The committee proposes that nobody in existing buildings should, over the next five years, be exposed to a radon daughter level of more than 2000 bequerel $(\mathrm{Bq})$ year $/ \mathrm{m}^{3}$, a total dose equivalent of $285 \mathrm{mSv}$ over 5 years. Existing houses should be altered before their inhabitants have received this total dose. This exposure will, it is estimated, mean that three people in every hundred will develop lung cancer after 60 years. As far as new buildings go, the committee proposes radon daughter concentrations of $70 \mathrm{~Bq} / \mathrm{m}^{3}(9 \mathrm{mSv} / \mathrm{yr})$ and at this exposure level, one person in every hundred will develop lung cancer after 60 years. According to the committee, these dose rates are the best that can be achieved at the moment, given the level of radioactivity in Swedish rock, soil and building materials.

The number of people who will develop cancer because of the high radon daughter levels may however be less than these estimates. According to a spokesman at the Radiation Protection Institute, current research into the risks of contracting cancer at certain concentrations of radon daughters shows that the risks to the ordinary man may have been overestimated. The risk estimates are based on studies of uranium miners, the concentrations around miners who developed cancer being extrapolated to the ordinary population. But these studies did not take into account the fact there is always more particulate matter in the air in mines than in ordinary houses. As radon daughters enter the body attached to airbone dust, the risk to the general public may have been overestimated.

Wendy Barnaby

\section{Women in science: some improvement, but still a long way to go}

There has been a considerable improvement in the status of women PhDs in academic science over the past decade, but further substantial gains are still needed before equal opportinuty is fully realised, according to a report published recently by a committee of the US National Academy of Sciences.

On the positive side, the report, prepared by the academy's committee on the education and employment of women in science and engineering, says that in the past decade women's share of all science doctorates has doubled, from $9 \%$ to $18 \%$, and is still increasing in all fields of science.

Furthermore women are occupying a growing proportion of research faculty positions, particularly in the larger institutions; in the top 25 research universities, for example, women account for $35 \%$ of the growth of science faculties since 1973 .

However there remain several areas of concern. One is that there continues to be a disproportionate number of women in two kinds of position: part-time instructors or lecturers which are outside the tenure stream offer little chance for productive research; and postdoctoral or research staff positions.

There are also areas in which the discrepancy between salaries for male and female research workers is giving continued cause for concern. The report points out, for example, that although the difference in postdoctoral stipends decreased from $5.7 \%$ to $4.9 \%$ between 1973 and 1975 , it had increased again to $7.5 \%$ by 1977 .

"On the basis of available data, it appears likely that at least a large part of the salary differences between men and women postdoctorals derives from bias. At this level no significant differences in overall ability or promise can be documented, and male and female scientists should be rewarded equally for comparable work. Systematic salary differences at this early career stage are important not only for their immediate relevance to equity, but also as a portent of future status," says the report.

Among the major conclusions of the report are that:

- rank for rank, women faculty continued to be tenured less often than men. For all ranks, $72 \%$ of the men but only $46 \%$ of the women hold tenure appointments, and this disparity is increasing

- in relation to the pools of new PhDs in the various fields, chemistry and mathematics employ far lower proportions of women faculty than other fields

- women account for all of the net growth in science faculty at the assistant professor rank for the top 50 US universities (by R \& $\mathrm{D}$ expenditures) and for nearly half of the increase in all other institutions

- wide field of variations in rank, salary, and tenure distribution for women faculty compared to men suggest that an assumed lack of mobility of married women is at most contributory rather than a primary reason for women's evident disadvantage.

The continued plight of women in science was emphasised at recent hearings before Senator Edward Kennedy's health subcommittee by Ms Anne Briscoe of the Association for Women in Science, who claimed that despite the results of affirmative action programmes, sexist attitudes were still deep-rooted. The health subcommittee is currently discussing a "Women in Science and Technology Equal Opportunity Act”. 